\title{
Biochemical, Physiological and Morphological Characterization of the Bacterial Isolate causing Stalk Rot of Sorghum as Erwinia chrysanthemi
}

\author{
Prachi Singh*, Yogendra Singh and Jyotika Purohit \\ Department of Plant Pathology, College of Agriculture, G. B. Pant University of Agriculture and \\ Technology, Pantnagar, Pin-263145, U.S. Nagar, Uttarakhand, India \\ *Corresponding author
}

\section{A B S T R A C T}

Keywords

Characterization, CPV medium,

Erwinia

chrysanthemi, Sorghum, Stalk rot.

Article Info

Accepted:

02 March 2017

Available Online:

10 April 2017
Stalk rot caused by Erwinia chrysanthemi is one of the most destructive diseases of sorghum crop. The bacterium was isolated from infected sorghum plants collected from livestock research centre, G.B. Pant University of Agriculture and Technology, Pantnagar, India. Biochemical, physiological and morphological characterization of the isolate was done for confirmation of the bacterium species. Bacterial suspension $[0.7 \%$ Tween-40 $\left.(\mathrm{v} / \mathrm{v})+1 \times 10^{7} \mathrm{cell} / \mathrm{ml}\right]$ of isolate was inoculated in leaf whorl with the help of atomizer for pathogenicity testing. Biochemical and physiological analysis confirmed the taxonomic assignation of $E$. chrysanthemi as the causal organism of stalk rot of sorghum. Growth assay on Erwinia specific medium, crystal violet sodium polypectate (CVP) medium, the specific medium for $E$. chrysanthemi at $37^{\circ} \mathrm{C}$, expressing characteristic deep pit, provided the confirmatory result. The typical stalk rot disease symptoms on sorghum plant, further validated the authenticity of the test microorganism.

\section{Introduction}

A plant pathogenic enterobacterium, Erwinia chrysanthemi is responsible for soft rot diseases in a wide range of plant species. However, strains from different host plants have variable pathogenic and phenotypic properties (Dickey, 1979; Janse and Ruissen, 1988). The genus Erwinia is named after one of the founder of phytobacteriology, Erwin Frank Smith, and was established by Winslow et al., (1917) to include the plant pathogenic entereobacteria. Erwinia are motile by peritrichous flagella, usually 8-11 flagellate (Dickey, 1981), gram-negative, non-spore forming, straight rod with rounded ends, and occurs singly or in pairs. Size of Erwinia ranges from $0.8-3.2 \times 0.5-0.8 \mu \mathrm{m}$ (average 1.8 $\times 0.6 \mu \mathrm{m}$ ) depending on carbon source present in the medium and growth conditions (Grula, 1970), stalk rot of sorghum caused by Erwinia chrysanthemi Burkholder, McFadden, and Dimock is one of the most destructive diseases of sorghum crop. The disease appears on sorghum stem as water soaked symptoms that later turns reddish dark brown colour. Saxena et al., (1991) reported, stalk and top rot of sorghum under natural conditions in India during 1987-1988 cropping season in sorghum field at Pantnagar, Uttarakhand. Loss due to stalk rot varies from season to season across the world and yield losses upto $60 \%$ have been reported in susceptible cultivars (Pande and 
Karunakaz, 1992). Disease incidence ranging from 7.50 to $46.85 \%$ in Tarai region of Uttarakhand has been also been reported by Kharayat and Singh (2013). A number of different biochemical methods are currently being employed for microbial identification and taxonomic classification. This study was designed to suggest a set of biochemical and physiological testing to characterize the isolate of destructive soft rot bacterium so that plant disease outbreak can be diagnosed at early stage and management strategies can be planned and implemented accordingly.

\section{Materials and Methods}

On the basis of visual observation, infected sorghum plants with typical soft rot symptoms were collected from livestock research centre, G.B. Pant University of Agriculture and Technology, Pantnagar in the growing season during the year 2014. Samples were kept in polythene bags under refrigerated condition at $4^{0} \mathrm{C}$.

Isolation of suspected bacterium was done for confirmation and the pathogen was identified by using a set of morphological, biochemical and physiological tests. The experiment was conducted at Centre of Advanced faculty training in Plant Pathology, Department of Plant Pathology, College of Agriculture, G.B. Pant University of Agriculture and Technology, Pantnagar, Uttarakhand, India.

\section{Isolations and purification of the isolate}

Isolation of bacterium was done as per the method described by Janse (2005). Pieces of tissue taken from the margin of healthy and diseased tissues were disinfected with $70 \%$ alcohol and placed in a sealed tube with sterile water. Tissues were left for $30 \mathrm{~min}$ in suspension so that the bacteria could diffuse out of the tissues. Subsequently $100 \mu$ of the suspension was plated onto crystal violet sodium polypectate (CVP) medium Characteristically deep-pit forming colony on CVP medium purified on yeast dextrose calcium carbonate medium by streaking using freshly growing single colony and these plates were incubated at $28^{\circ} \mathrm{C}$ for five days. The isolate was preserved in NA slants at $4^{0} \mathrm{C}$.

\section{Pathogenicity tests}

To confirm the pathogenicity of isolate, leaf whorl inoculation was done on plant of 21 days old susceptible sorghum cultivar under controlled glasshouse conditions. Isolate was grown on Luria Broth for $24 \mathrm{~h}$ at $28^{\circ} \mathrm{C}$.

The bacterial cells were suspended in sterile distilled water and the cell density adjusted to $1 \times 10^{7} \mathrm{cfu} / \mathrm{ml}$. Bacterial suspension $[0.7 \%$ Tween-40 (v/v) $\left.+1 \times 10^{7} \mathrm{cell} / \mathrm{ml}\right]$ of isolate was inoculated in leaf whorl with the help of atomizer for pathogenicity testing of the test bacterium. The control was sprayed with sterilized water. Experiment was conducted thrice to confirm the result.

\section{Biochemical, physiological and morphological characterization of the pathogen}

Test pathogen was screened for characterization up to species level by using a set of biochemical and physiological tests to detect the presumptive E. chrysanthemi.

\section{Morphological tests}

\section{Logan's medium}

The bacterial isolate was transferred onto Logan's medium by streaking bacterial suspension of $10^{4} \mathrm{cfu} / \mathrm{ml}$, and incubated at $27^{\circ} \mathrm{C}$ for $24 \mathrm{~h}$. After incubation Ech shows dark red colonies with a red centre. The experiment was replicated thrice. 


\section{Yeast Dextrose Calcium Carbonate Agar (YDC) medium}

The slanted surface of the test medium YDC was streak-inoculated with a loopful of the inoculum of the medium and incubate at $27^{\circ} \mathrm{C}$. Observation on growth and development of a blue coloration (alkaline reaction) for 7, 14 and 21 days were recorded. A light blue colour is considered to be a negative reaction. The experiment was replicated thrice.

\section{Nutrient Agar (NA) medium}

The slanted surface of the test medium NA was streak- inoculated with a loopful of the inoculum and incubated at $27^{\circ} \mathrm{C}$. Growth and the development of colony was observed for 7 days. The experiment was replicated thrice.

\section{Scanning electron microscopy}

SEM preparation for E. chrysanthemi Pantnagar isolate was done using procedure described by Kaláb et al., (2008). Twentyfour hours old actively growing bacterial cells on Luria broth medium were harvested by centrifuge at 10,000 rpm. Then, the bacterial cells were fixed with $2.5 \%$ gluteraldehyde in $0.05 \mathrm{M}$ sodium phosphate, $\mathrm{pH} 6.8$, for $24 \mathrm{~h}$ at $4^{\circ} \mathrm{C}$, washed with sodium cacodylate buffer three times (10 min each wash). They were finally fixed in $1 \%$ osmium tetraoxide for $1 \mathrm{~h}$ and washed with $0.1 \mathrm{M}$ sodium cacodylate buffer as before. Further, the cells were dehydrated through a series of graded acetone $(10,20,30,40,50,70,80,90$ and $100 \%)$. These cells were soaked for $15 \mathrm{~min}$ at each concentration. The drying was completed by placing the sample in a flow of $\mathrm{CO}_{2}$ in critical point dryer. The cells were mounted on aluminium stubs and coated with gold using Hummer V sputter coater, and viewed and photographed under a scanning electron microscope.

\section{Biochemical and physiological tests}

\section{Citrate utilization}

The citrate test was performed by inoculating $100 \mu \mathrm{l}$ of a $10^{4} \mathrm{cfu} / \mathrm{ml}$ of Ech into plate containing the Simmon's citrate agar medium, where sodium citrate is the only source of carbon and energy. Then all plates were incubated at $37^{\circ} \mathrm{C}$ for $48 \mathrm{~h}$. Bromothymol blue is used as an indicator from sodium carbonate an alkaline product, which changes the colour of indicator from green to blue and this constitutes the positive test.

\section{$3 \% \mathrm{KOH}$ test}

Placed approximately $50 \mu \mathrm{l}$ of $3 \%$ (w/v) $\mathrm{KOH}$ on a clean glass slide, aseptically transferred bacterial cells from an agar plate to the drop of $\mathrm{KOH}$ with a sterile toothpick, the cells were agitated with the toothpick. The viscosity of the drop increased and a string of "goo" easily picked up with the tip of the toothpick, the cells are gram-negative (Suslow et al., 1982). If the viscosity does not greatly increase, the cells are gram-positive. The experiment was replicated thricely.

\section{Sensitivity to erythromycin at $15 \mu \mathrm{l} / \mathrm{ml}$}

Sensitivity of erythromycin at $15 \mu \mathrm{l} / \mathrm{ml}$ concentration (Dickey and Kelman, 1988) was determined on Nutrient Agar medium. Sterile paper disk was dipped in erythromycin at 15 $\mu 1 / \mathrm{ml}$ conc. solution and placed aseptically in NA medium. Blank disk which was dipped in sterile water, placed on same plate served as control and incubated at $27^{\circ} \mathrm{C}$ for $48 \mathrm{~h}$. The experiment was replicated thricely.

\section{Blue pigment production on Nutrient Glycerol Manganese Chloride (NGM) medium}

Medium was allowed to cool up to $45^{\circ} \mathrm{C}$, and poured into Petri dishes under aseptic 
conditions. A bacterial streak showing a dark brownish to blue colour was considered a positive reaction. For observation of colony morphology, $100 \mu \mathrm{l}$ of bacterial suspension $\left(10^{3} \mathrm{cfu} / \mathrm{ml}\right)$ was pipette onto the surface of the NGM agar plate, and spread evenly with an L-shaped rod. The plate was incubated for 2 to 3 days at $28.8^{0} \mathrm{C}$ with three replications prior to observation.

\section{Deep pit formation on Crystal violet pectate (CPV) medium}

Test for the development of liquefied pits was performed on CPV (crystal violet pectate) medium as described by Cuppels and Kelman (1974). The bacterial suspension of isolate was uniformly distributed with a glass rod on the surface of medium. Observation of pits created around colonies were taken within five days of incubation at $28^{\circ} \mathrm{C}$. The isolation of Erwinia spp. using the selective media is based on the ability of the pathogen to hydrolyse polypectate and to form typical cup shaped pit (cavities) in the medium. As was shown by Perombelon (1972), other pectolytic bacteria occurring in the soil, especially certain pseudomonads, also form cavities, but these are shallow and quite distinct from those caused by varieties of $E$. carotovora, which are easily recognized even when there is overcrowding by other organisms. The experiment was replicated thrice.

\section{Results and Discussion}

A bacterium isolated from sorghum stalk showing suspected soft rot symptom was clearly established as soft rot bacterium by biochemical, physiological and morphological tests. The set of biochemical and physiological tests used to detect the presumptive $E$. chrysanthemi which were found negative-included gram staining, 3\% $\mathrm{KOH}$ test and oxidase test. The tests showing positive results included:- red colonies on Logan's medium, deep pit formation on crystal violet sodium polypectate, CVP medium $+0.4 \%$ tetrazolium chloride solution at $37^{\circ} \mathrm{C}$, indole production, sensitivity to erythromycin at $15 \mu \mathrm{g} / \mathrm{ml}$, undulated margin on NA medium, $\mathrm{H}_{2} \mathrm{~S}$ production, gelatin liquefaction, Simmons citrate agar medium (having bromothymol blue indicator) colour changes from green to dark blue, colony morphology on yeast dextrose calcium carbonate agar medium (YDC), and Growth at $37^{\circ} \mathrm{C}$ was profuse within $2-3$ days.

When grown on nutrient agar, the pectolytic Erwinia form round and whitish colonies (Dowson, 1957). Whereas on selective pectate media e.g. CPV (Cuppels and Kelman, 1974) they produce deep cavities containing iridescent, translucent and crisscrossed colonies with internal markings (Lelliott and Stead, 1987). Test organism of 'Erwinia carotovora' group is recognized by the characteristic cavities that they form on selective CPV (Crystal violet pectate) medium (Cuppels and Kelman, 1974). The subsequent specific and subspecific differentiation is obtained by observing the pectolytic activity (on CPV) of the test organism at different temperatures. If cavities are formed at $27^{\circ} \mathrm{C}$, the test isolate could be a strain of any of the three Erwinia. Cavity formation at $35.5^{\circ} \mathrm{C}$ would eliminate the possibility of it being E. carotovora subsp. atroseptica and at $37^{\circ} \mathrm{C}$ the only remaining possibility would be E. chrysanthemi. Farmer et al., (1980) reported that colour change from green to dark blue on Simmons citrate agar medium (having bromothymol blue indicator) is important character of enterobacteriaceae. The E. chrysanthemi isolate do not produce water-insoluble blue pigment (indigoidine) on $\mathrm{NGM}$ (Nutrient Glycerol $\mathrm{MnCl}_{2} \cdot 4 \mathrm{H}_{2} \mathrm{O}$ (2 $\mathrm{mM}$ ) agar medium. 
Fig.1 Scanning electron micrograph showing straight rod shaped E. chrysanthemi cells

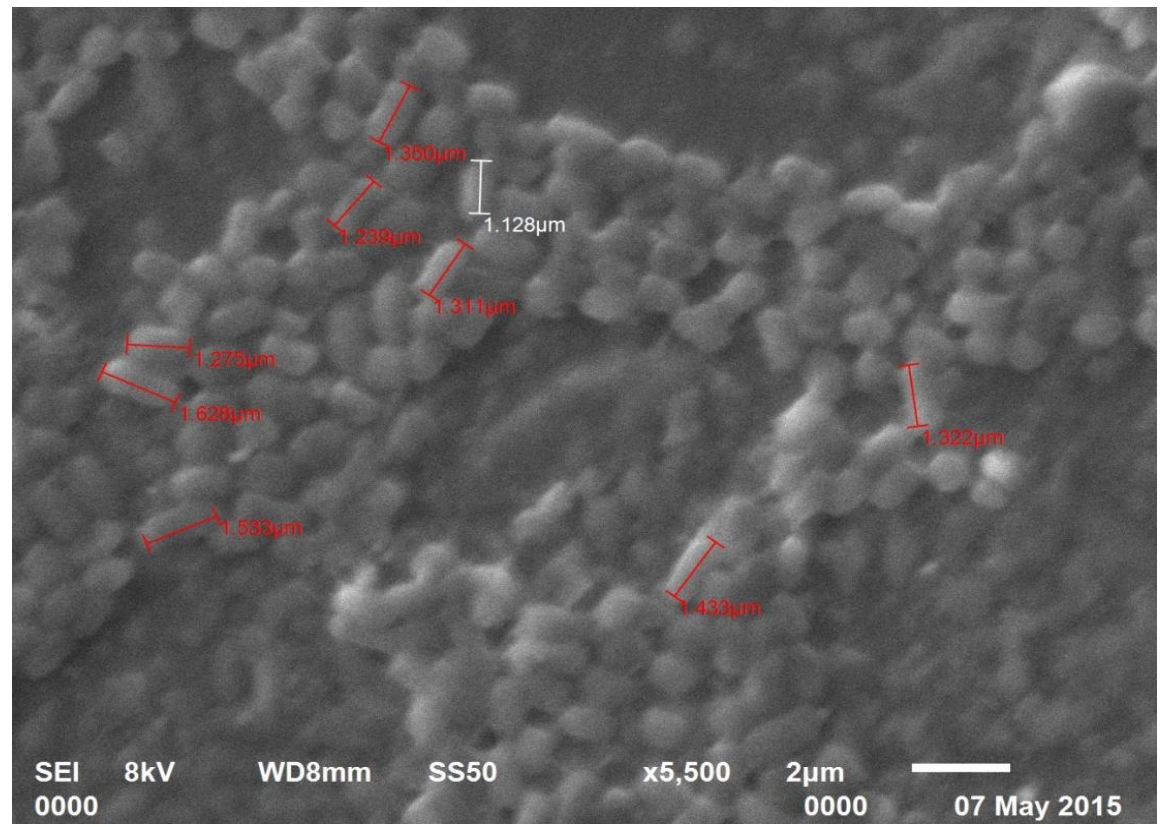

The production of blue pigment is influenced by the composition of the growth medium and has become a variable trait among wild-type strains of E. chrysanthemi (Reverchon et al., 2002). Such instability in pigment phenotype might result from the different growth media used. Thus, E. chrysanthemi is not usually differentiated from other Erwinia spp. on the basis of blue pigment production, and should be defined by several biochemical and physiological tests (Reifschneider and Lopes, 1982).

SEM analysis showed the shape and size of bacterium, straight rod with rounded ends and $1.37 \times 0.50 \mu \mathrm{m}$ respectively (Fig. 1). In pathogenicity test, the bacterium was found potential pathogen as it produced typical symptoms on stalk of sorghum plant as naturally occurred in field conditions after 5 days of inoculation. The pathogen mainly affected sorghum stem showing water-soaked symptoms that later turned reddish dark brown colour in 2-3 days. The infected stem pith disintegrated and showed slimy soft-rot symptoms after 10 days of inoculation. Similar symptoms have been reported in sorghum by; Saxena et al., 1991; Hseu et al., 2008.

In conclusion physiological, biochemical and morphological methods are user friendly, convenient, reproducible, rapid and inexpensive than molecular and serological methods and can be readily used for identification of E. chrysanthemi. Selection of appropriate method for identification of bacterium is essential for systematic and pathological study. As the bacterium produced typical stalk rot disease symptoms on sorghum plant and characteristic deep pit on crystal violet sodium polypectate (CVP) medium at $37^{\circ} \mathrm{C}$ it was confirmed to be Erwinia chrysanthemi.

\section{References}

Burkholder, W.H., McFadden, L.A. and Dimock, A.W. 1953. A bacterial blight of chrysanthemums. Phytopathol., 43: 522526.

Cuppels, D. and Kelman, A. 1974. Evaluation of selective media for isolation of soft-rot bacteria from soil and plant tissue. Phytopathol., 64: 468-475. 
Dickey, R.S. 1979. Erwinia chrysanthemi: A comparative study of phenotypic properties of strains from several hosts and other Erwinia species. Phytopathol., 69: 324-329.

Dickey, R.S. 1981. Erwinia chrysanthemi: reaction of eight plant species to strains from several hosts and to strains of other Erwinia species. Phytopathol., 71: 23-29.

Dowson, W.J. 1957. Plant Diseases Due to Bacteria. $2^{\text {nd }}$ edition. Cambridge University Press. Cambridge, England. pp. 232.

Farmer, J.J., Asbury, M.A., Hickman, F.W. and Brenner, D.J. 1980. Enterobacter sakazakii: A new species of "Enterobacteriaceae" isolated from clinical specimens. Int. J. Systematic Bacteriol., 30: 569-584.

Grula, M.M. 1970. Cell size of Erwinia sp. as influenced by composition of medium. Canadian J. Microbiol., 16(12): 1363-1365.

Hseu, S.H.; Kuo, K.C.; Lin, H.F. and Lin, C.Y. 2008. Bacterial stalk rot of sorghum occurred in Kimmen area caused by Erwinia chrysanthemi. Plant Pathol. Bull., 17: 257- 262.

Janse, J.D. 2005. Phytobacteriology: Principles and Practices. CABI Publishing. pp. 366.

Janse, J.D. and Ruissen, M.A. 1988. Characterization and classification of Erwinia chrysanthemi strains from several hosts in the Netherlands. Phytopathol., 78: 800- 808 .

Kaláb, M., Yang, A.F. and Chabot, D. 2008. Conventional Scanning Electron Microscopy of Bacteria. Infocus. pp. 44-61.

Kharayat, B.S. and Singh, Y. 2013. Unusual occurrence of erwinia stalk rot of sorghum in tarai region of Uttarakhand. Int. J. Agri. Sci., 9(2): 809-813.
Lelliott, R.A. and Stead, D.E. 1987. Methods for the diagnosis of bacterial diseases of plants, vol. 2. Blackwell Scientific Publications. Oxford, London. pp. 216.

Pande, S. and Karunakaz, R.I. 1992. Stalk rots. Sorghum and millets diseases: a second world review. pp. 219-234.

Pérombelon, M.C.M. 1972. The extent and survival of contamination of potato stocks in Scotland by Erwinia carotovora var. carotovora and $E$. carotovora var. atroseptica. Annals of Appl. Biol., 71(2): 111-117.

Reifschneider, F.J.B. and Lopes, C.A. 1982. Bacterial top and stalk rot of maize in Brazil. Plant Dis., 66: 519-520.

Reverchon, S., Rouanet, C., Expert, D. and Nasser, W. 2002. Characterization of indigoidine biosynthetic genes in Erwinia chrysanthemi and role of this blue pigment in pathogenicity. J. Bacteriol., 184: 654655.

Saxena, S.C., Mughogho, L.K., and Pande, S. 1991. Stalk rot and top rot of sorghum caused by Erwinia chrysanthemi. Indian J. Microbiol., 31(4): 435-441.

Suslow, T.V., Schroth, M.N. and Isaka, M. 1982. Application of a rapid method for gram differentiation of plant pathogenic and saprophytic bacteria without staining. Phytopathol., 149(2): 77-82.

Winslow, C.E.A., Broadhurst, J., Buchanan, R.E., Krumwiede, C.J., Rogers, L.A. and Smith, G.H. 1917. The families and genera of the bacteria. Preliminary report of the committee of the society of American Bacteriologists on characterization and classification of bacterial types. $J$. Bacteriol., 2: 505-566.

\section{How to cite this article:}

Prachi Singh, Yogendra Singh and Jyotika Purohit. 2017. Biochemical, Physiological and Morphological Characterization of the Bacterial Isolate causing Stalk Rot of Sorghum as Erwinia chrysanthemi. Int.J.Curr.Microbiol.App.Sci. 6(4): 341-346.

doi: https://doi.org/10.20546/ijcmas.2017.604.037 